Ivana Kostadinović ${ }^{1}$

University of Niš, Faculty of Economics, Serbia

Marija Petrović-Ranđelović ${ }^{2}$

University of Niš, Faculty of Economics, Serbia
SCIENTIFIC REVIEW ARTICLE doi:10.5937/ekonomika1504097K

Received: September 17, 2015

Accepted: November 05, 2015

\title{
THE ROLE AND IMPORTANCE OF FREE ZONES IN ECONOMIC DEVELOPMENT: THE EXPERIENCE OF THE REPUBLIC OF SERBIA AND THE EUROPEAN UNION ${ }^{3}$
}

\begin{abstract}
In the modern business conditions, the creators of the new industrial policy pay increasing importance to the development of free zones as an important instrument of business infrastructure. Free zones offer huge chances for the establishment and development of small and medium-sized enterprises and improving their overall business. Experience has shown that many countries owing to the free zones achieve significant development results in comparison with other countries. The countries that have developed free zones generate: significant inflow of foreign direct investment and new technologies, rising living standards and increasing employment. Those countries that develop free zones have a greater competitive advantage, achieve faster economic development and efficiently engage in international flows. The aim of this paper is to, based on a comparative analysis of business zones in the Republic of Serbia and the European Union, indicate that the Republic of Serbia in recent years has improved its position and the investment climate, so that operation of the free zone is a lot easier. Whether the free zones in one country, and in the Republic of Serbia will be successful, depends primarily on the country's attitude towards the concept of free zones and how that affects their development, as well as the new industrial policy, its objectives and instruments. It is important to emphasize that the role of the state has changed significantly in the development of free zones, which includes as well a brighter and better future in terms of stable operation of the free zones and achieve significant results.
\end{abstract}

Key words: free zones, economic development, foreign direct investment, Republic of Serbia, EU.

JEL classification: E66, O10, O38

\footnotetext{
${ }^{1}$ ivana.kostadinovic@eknfak.ni.ac.rs

2 marija.petrovic@eknfak.ni.ac.rs

${ }^{3}$ Acknowledgements: Improving the competitiveness of the public and private sector by networking competences in the process of european integration of Serbia, Project no. 179066, financed by the Ministry of Education, Science and Technology Development - Republic of Serbia.
} 


\title{
УЛОГА И ЗНАЧАЈ СЛОБОДНИХ ЗОНА У ПРИВРЕДНОМ РАЗВОЈУ: ИСКУСТВО РЕПУБЛИКЕ СРБИЈЕ И ЕВРОПСКЕ УНИЈЕ
}

\begin{abstract}
Anстракm
У савременим условима пословања креатори нове индустријске политике све већи значај поклањају развоју слободних зона као важном инструменту пословне инфраструктуре. Слободне зоне пружају огромне шансе за оснивање и развој малих и средњих предузећа и доприносе побољшању юиховог укупног пословања. Пракса је показала да многе земье захваљујући слободним зонама остварују значајне развојне резултате у поређењу са другим земљама. Наиме, земље које имају развијене слободне зоне остварују: значајан прилив страних директних инвестиција и нових технологија, пораст животног стандарда и повећање запослености. Оне земље које развијају слободне зоне имају већу конкурентску предност, остварују бржи привредни развој и ефикасније се укључују у међународне токове. Циљ овог рада је да на основу компаративне анализе пословања зона у Републици Србији и Европској унији, укаже да је Република Србија у последње време побољшала своју позицију и инвестициону климу, тако је да је пословање слободних зона доста олакшано. Да ли ће слободне зоне у једној земљи, па и у Републици Србији бити успешне, зависи првенствено од односа државе према самом кониепту слободних зона и начина на који утиче на юихов развој, као и од нове индустријске политике, ьених ичљева и инструмената. Значајно је истаћи да се улога државе знатно променила у развоју слободних зона, као и да постоји светлија и боља будућност у погледу стабилнијег функиионисања слободних зона и остварења значајних резултата.
\end{abstract}

Кључне речи: слободне зоне, економски развој, стране директне инвестиције, Република Србија, ЕУ.

\section{Introduction}

The process of transformation and structural adjustment of the economy of countries in Eastern and Central Europe started in the eighties of the last century and represents a sort of "catching up" with the developed Western European economies, but at a low level. (Gligorijević, Petrović, 2008, p. 21)

Applying the concept of free zones is very important and desirable in all countries, as well as in the Republic of Serbia, considering that as an important instrument of a new industrial policy, if it's properly places and designed, can lead to achieving the goals of economic development. Because of that, this concept is accepted in developed counties, and supported by the world's great institutions and the European Union. Future economic development of the Republic of Serbia must have a much greater relay on new forms of business, in which free zones and industrial parks play an important role.

In the previous period of development, there were no favourable conditions in the operating of free zones in the Republic of Serbia, which significantly influenced the 
diversion decisions of foreign investors. However, in the last few years, the conditions of business have been improved, as well as the investment climate, all of which significantly positively influenced stable business of free zones in the Republic of Serbia.

In the last twenty years, free zones have become more popular, so that every country has its own motives for their formation. Government must assess positive and negative aspects of the formation of free zones. The fact is that, free zone will be useful for the host country if: attracts direct foreign investments, thus increasing foreign exchange inflow and exports, attracts transfers of modern technology and if recruit and activate unemployed local workforce. Aside from that, the zone can have a very positive impact on the overall environment and is in the function of regional development.

The institute of free zones should facilitate and speed up the latest development of domestic production in one country, with many exemptions (customs, tax) and benefits in order to increase the export of goods. Modern free zones should enable modern advanced production, with new modern technologies with the appropriate customs and foreign trade benefits. In that way, the goods produced in those zones will be competitive in the world's markets, and will enable faster integration of domestic economy into international economic flows and international economic integrations.

In accordance with the laid goal, this paper is structured as follows. After introductory considerations, we will give an overview of the main features of free zones in the Republic of Serbia. In the second part of the paper, the authors give the analysis of the European experiences in forming the free zones.

\section{The Features of Free Zones in the Republic of Serbia}

The fact is that the host country since founding the free zones, expect to achieve certain benefits, such as increasing employment, greater inflow of direct foreign investments and access to modern technology. However, due to the lack of reliable data, it is very difficult to accurately estimate the costs and profit, that is how much the expectation is achieved during the time. When the host country assesses advantages, that is, the benefits, which it can have from existence of free zones, then it's necessary to compare the benefits with total costs. Benefits would certainly be revenue achieved from domestic production, with the use of local materials and equipment without any taxes and with hiring local work force. On the other side, the costs would include only expenditure for maintenance of zones, as well as certain payments for the use and maintenance of infrastructure.

When a country decides to form the free zone, it must assess positive and negative effects on their formation, must provide the necessary conditions for business, in order to achieve greater efficiency. In fact, the following conditions should be considered: legal and political stability and security, tax exemptions during export/import of goods from the zone, as well as exemption from custom duties, developed infrastructure, favourable investment climate, warehouses for storage of goods, than, not less important, water, electricity, gas, heating, sanitation, telephone, internet, well-organized transport, as well as the existence of a good banking system, parking, and of course, inevitable administration records. These are generally conditions that would attract direct foreign investments.

Foreign investors, when making investment decisions give a great importance to that element of the investment climate, which refers to the legal and political stability and 
security. This immediately implies that each country who plans to form a free zone, and it is necessary to bring the Law that will protect it from other countries. Aside from that, it is necessary to have certain rules for easier establishment and operations of companies in the zone, as well as regulations to facilitate the employment of labour.

Adoption of the Law of Free Zones in the mid of 2006, as well as improving access and strengthening state support, contributed to increasing the efficiency of business operations within the free zone in the Republic of Serbia. There is a need for synchronization, amending, and adopting new institutional arrangements, in the field of labour relations, taxes, duties, building land, environmental protection, and other areas, affecting along with the creation of a favourable business environment.

Besides the Government, a very important role in functioning and development of free zones has The Free Zones Administration at the Ministry of Finance, which began in late 2008. Considering that the Republic of Serbia until 2008 did not have a professional body that would deal with issues related to the free zone, the constitution of the Board made a great progress in the smooth functioning zone. In fact, there was a plan to bring certain benefits for work in areas such as the abolition of the tax on corporate profit tax, exemption from payment of tax on labour earnings for all jobs, and exemption from city and municipal taxes in the construction of new facilities in the zone. There is a suggestion that in the period ahead, the income tax should be abolished too, which will be a great stimulus for foreign investors in the Republic of Serbia. A special task of the Free Zones is the cooperation with EU free trade zones and free zones associations of the EU, so that with the analysis of subsidies allowed in the EU, the proposed legislative solutions could create the most favourable business environment for the free zone. (Ministarstvo finansija Republike Srbije, Uprava za slobodne zone, 2011, str. 22). Representatives of the Free Zones expect that by 2020 the Republic of Serbia will be covered with a network of free zones, which will with simple customs procedures and operations without paying customs duties, attract investors from around the world and an industry "hub" in Southeastern Europe. (Ministarstvo finansija Republike Srbije, Uprava za slobodne zone, 2011).

Free Zones, as an important element of the customs system of the Republic of Serbia, are set to be a function of exports, because they give various benefits and exemptions from payment of duties and tariffs on goods imported into the Serbian free zone, and exported exclusively to the foreign markets. This means that, taking into account the geographical location of the area, cheap labour, benefits and facilities for the payment of customs duties, they may become an important factor in the future exports of the Republic of Serbia.

According to sources of the Customs Administration, the largest exporters of the Republic of Serbia in the period from January 2013 to November 2013 were companies "Fiat Automobiles Serbia", "Petroleum Industry of Serbia" and "Tigar Tyres", which were operating in the free zone regime in the Republic of Serbia. "Fiat Automobiles Serbia" operates in the "FAS free zone" in Kragujevac and is the biggest exporter of the Republic of Serbia. The company has achieved a total export amount of over 1.46 billion Euros during this period (Ministarstvo finansija Republike Srbije, Uprava za slobodne zone, 2015b). 
Table 115 largest exporters in the period January - November 2013

\begin{tabular}{|c|c|c|c|}
\hline No. & Name of the exporter & Place & Export $^{*}$ \\
\hline 1. & Fiat automobili & Kragujevac & $1.416,10$ \\
\hline 2. & Naftna industrja Srbije & Novi Sad & 270,80 \\
\hline 3. & Tigar Tyres & Pirot & 216,9 \\
\hline 4. & HIP-Petrohemija & Pančevo & 215,2 \\
\hline 5. & Hemofarm & Vršac & 147,1 \\
\hline 6. & Gorenje & Valjevo, Stara Pazova & 139,7 \\
\hline 7. & Tarkett & Bačka Palanka & 127,6 \\
\hline 8. & Železara Smederevo & Smederevo & 123,3 \\
\hline 9. & Yura Corporation & Rača & 107,9 \\
\hline 10. & Valy & Belosevac & 106,6 \\
\hline 11. & RTB Invest & Bor & 99,9 \\
\hline 12. & Impol Seval & Sevojno & 91,2 \\
\hline 13. & Ball pakovanja Evropa BEO & Beograd & 90,7 \\
\hline 14. & Sirmimum Steel & Sremska Mitrovica & 89,7 \\
\hline 15. & Tetra Pak Production & Beograd & 89,5 \\
\hline
\end{tabular}

In mill. EUR

Source: Ministarstvo finansija Republike Srbije, Uprava za slobodne zone, (2015a) http://www.usz.gov.rs/aktuelno.php\#44 (6.2.2015)

Viewed by the value of exports in the period from January to November in 2013 (Table 1), "Petroleum Industry of Serbia", which operates within the free zone "Novi Sad", is on the second place as the largest exporter with realized value of exports in the amount of 270.80 million Euros. In third place is the company from Pirot "Tigar Tyres", which, with the realized value of exports in the amount of 216.9 million Euros, has positioned itself among the most successful exporters in Serbia.

Free Zone of the Republic of Serbia in 2013, achieved a turnover of approximately 4 billion Euros, which is $30 \%$ more than the previous year, they employed more than 18,000 people and operate 220 companies. The share of domestic production materials in the production is particularly important, which compared to the 2012 , increased by $260 \%$. At the same time, exports of goods from free zones increased by $143 \%$ to 2.1 billion Euros, which is one fifth of total exports from Serbia. (Privredna komora Srbije, Slobodne zone, 2014, p. 19)

Exports and placement of goods to the market of the Republic of Serbia, as well as the value of services provided in a free zone increased in comparison to 2012 for $99.77 \%$. According to available data, the exports of goods in 2013, is higher than in the previous year by a substantial $143.15 \%$. The share of exports of goods from the free zones in the total export of the Republic of Serbia in 2013 amounted to $19.68 \%(2,164,558,008.00$ Euros), representing an increase of $9.61 \%$ compared to 2012. (Ministarstvo finansija Republike Srbije, Uprava za slobodne zone, 2014, p. 43).

According to the Agency for promotion and foreign investment in the Republic of Serbia exported goods worth about 10,999,000,000.00 Euros in 2013. On the list of the fifteen largest exporters in the Republic of Serbia in 2013, were enterprises, users of free zones, "Fiat Automobiles Serbia", "Copper Mill”, "Tiger Tyres", "Impol Seval” and "Siemens". 
The total value of the realized turnover of goods and services increased by $97.44 \%$. This increase was influenced by growth in the value of imports of goods, exporting and selling of goods on the market of the Republic of Serbia, as well as the value of services provided in a free zone. The value of imports of goods in comparison with 2012 increased by $55.55 \%$, while imports of raw materials increased by $57.18 \%$ and imports of finished products for 39.32\%. (Ministarstvo finansija Republike Srbije, Uprava za slobodne zone, 2014, p. 43).

On the territory of the Republic of Serbia in 2013 functioned nine free zones, namely: Free zone "Pirot" Free Zone "Zrenjanin," Free Zone "Subotica" Free Zone "Novi Sad", "FAS Free Zone", Kragujevac, Free zone "Sabac" Free Zone "Uzice" Free Zone "Smederevo" and Free Zone "Krusevac". The total value of realized turnover of goods and services in 2013 over the said free zones amounted to 4,935,117,473.00 Euros. In comparison with 2012, the total turnover increased by $97.44 \%$. The increase in turnover was affected by an increase in imports of goods, raw materials and finished products, as well as an increase in exports of goods. Imports of goods increased by $55.55 \%$ compared to 2012 , and to $57.18 \%$ for intermediate goods, while imports of finished products increased by $39.32 \%$. Exports of goods increased by $143.15 \%$ compared to 2012, while the export of goods to the market of the Republic of Serbia increased by $221.35 \%$ compared to 2012 . The value of the services provided in the free zones is higher in comparison to the year 2012 for $99.77 \%$. That increase the total value realized turnover of goods and services in 2013 was affected by a significant increase in the total value of realized traffic free zone "Kragujevac" for $170.55 \%$, the Free Zone "Zrenjanin" for $188.23 \%$ and an increase in realized turnover of Free Zone "Subotica" to 24,33\%. (Ministarstvo finansija Republike Srbije, Uprava za slobodne zone, 2014, p. 3)

On the list of the best free zones in the world, which traditionally publishes the prestigious newspaper "Financial Times", there are two free zones in the Republic of Serbia, among 34 best free zones. These are: Free Zone "Zrenjanin" which won the award in the category of incentives offered to investors, and Free Zone "Pirot "in the category of incentives offered for reinvestment (Ministarstvo finansija Republike Srbije, Uprava za slobodne zone, 2015c).

1) Free zone "Pirot" as one of the most successful zones, located on the international route (E-80), the Corridor 10 covers an area of 102 ha 65 a $63 \mathrm{~m}^{2}$. The operations started in April 1998 and since then has reached excellent results and became the leading free zone in the region and achieved positive export effects. Unlike other zones, which generally operate as a commercial free zone, this zone is an exception and it functions as an export-production and improves the overall export of the Republic of Serbia. The goal of this zone is the construction of infrastructure and providing the best possible customer service. It engages in producing mixture to produce passenger and truck tires, with the help of two strong joint venture company Michelin from France and Tigar AD from Serbia.

Free zone "Pirot" currently has eight production programs, one of which is the dominant plant for the production of tires (Michelin) allowing the use of the free zone as export processing zones (export processing zones). This has enabled the testing mode with production activities in the free zones in the Republic of Serbia and thus provided a response that the use of free zones in the function of production for export gives good results. (Vlada Republike Srbije, 2011, p. 10) 
It is worth noting that at the level of the Michelin group decided on future investment in the expansion of production capacity to 8,000,000 pieces of gum in 2013 to 12 million pieces of rubber by 2016 , and the plan is to bring about an increase in production by $50 \%$ to the value of $215,000,000.00$ Euros. In the area of the planned construction of an intermodal terminal, which along with the completion Construction of Corridor 10 will be an extra incentive for foreign investors to invest in the less developed part of Serbia. Besides that, Zone Pirot provides its customers the following services (Kozomara, 2003, p. 174): monitoring zone users, production and storage, forwarding, the container terminal, organization of international transport, storage of goods.

Companies operating in the area and contributing to the positive results achieved are: "Tigar Tyres" - production of car tires; "TIGAR FOOTWEAR"' - production of rubber footwear; "TIGAR TECHNICAL RUBBER"” - the manufacture of tires; "Novadis"- equipment for fishing; "ELISA PRO" - herbal and cosmetic products; "RBL" - for packaging of food products.

Free zone "Pirot" achieved in 2013, total exports of goods in the amount of 277,567,753.00 Euros. The total export of goods from a free zone, the share of goods produced in the free zone is $86.70 \%$, or $240,655,047.00$ Euros. Compared to the year 2012 , the total exports of goods increased by $10.27 \%$, but the export of goods manufactured in the free zone increased by $17.29 \%$. Imports of goods compared to the 2012, also increased by $33.49 \%$. Imports of raw materials increased by $12.11 \%$, while imports of finished products increased by $249.43 \%$. (Ministarstvo finansija Republike Srbije, Uprava za slobodne zone, 2014, p. 6). The Free zone "Pirot" realized a total turnover amounting to $547,874,006.00$ Euros. Turnover in this free zone increased by $14.18 \%$ compared to 2012 . The total value of goods sold and services rendered increased by $3.84 \%$.

Free zone "Pirot" has a very good cooperation with foreign partners and thus represents one of the pillars of the development of the town of Pirot, and the entire region. The continuous inflow of foreign capital in the previous period provides certainly increase in foreign exchange earnings from exports of goods from the zone and also affects the increase of employment, not only in the zone, but also to the entire municipality and the wider region. Free zone "Pirot", in 2014 was the second time among the 34 best zones in the world and in the "Financial Times", was the most successful in the field of reinvestment. The turnover of 500 million Euros is an imposing figure, and achieved by companies operating within the Zone and have approximately 5,000 employees.

The fact is that Zone Pirot achieved outstanding results and it is on par with some areas of the world, although the business climate could be improved if they introduced some tax breaks, such as a zero corporate income tax within the limits Zone. Such move of policy makers will contribute to improving the competitiveness of Pirot zone relative to the zone in the region.

2) As a second zone that achieves impressive results is Free Zone "Zrenjanin". FDI Magazine proclaimed this zone the best in Europe in the category of incentives offered to investors. This zone offers exemption from customs duties when importing and exporting raw materials, equipment, and materials for infrastructure, as well as many other benefits.

Free Zone "Zrenjanin" was founded in 2005 and has an area of 98 ha. The development strategy of the town of Zrenjanin is planned to establish these zones, with the aim of attracting foreign investors and creating new jobs for faster economic develop- 
ment of the entire region. Free Zone should enable the construction of infrastructure, transfer of new technologies and expertise, with easier hiring of unemployed workforce and ensuring better living standards of the population and rapid industrial development. Companies operating in the Zone "Zrenjanin" are: "KOLPA" - manufacturing shower, bath tub and hydro massage device; "LK Armature" - production of steel pipes and "Draexlmaier" - production of parts for the automotive industry. Activities carried out within these companies are: production of goods, warehousing and the same material for playback, the entire logistics, sales, import, export goods, insurance business, finances, tourism services, etc.

The Zone achieved significant results, as evidenced by the following data. The Free Zone "Zrenjanin" realized a total turnover amounting to 256,316,329.00 Euros. Turnover in this free zone increased by $188.23 \%$ compared to 2012 . The total value of goods sold and services rendered increased by $188.74 \%$. (Ministarstvo finansija Republike Srbije, Uprava za slobodne zone, 2014, str. 4). Free Zone “Zrenjanin" realized export of goods in the amount of 83,292,506.00 Euros. The total export of goods from a free zone, the share of goods produced in the free zone is $99.57 \%$, or $82,932,713.00$ Euros. The total exports of goods increased by $87.69 \%$, while the export of goods manufactured in the free zone increased by $87.65 \%$ compared to the 2012 . Imports of goods compared to the 2012 increased by $187.63 \%$, while imports of intermediate goods increased by $190.86 \%$, while imports of finished products increased by $24.18 \%$. Such a significant increase in the total exports and imports in 2012 was a result of operations of the company "DAD Draexlmaier Automotive" Ltd. located in a free zone which is a partner of "Fiat Automobiles Serbia" and which had total exports of goods in the amount of 76,541,916.00 Euros, while the total export of goods in total "FAS Free Zone", Kragujevac was 52,307,763.00 Euros. (Ministarstvo finansija Republike Srbije, Uprava za slobodne zone, 2014, p. 7)

3) "FAS Free Zone", Kragujevac had the largest export of goods in the amount of $1,419,077,969.00$ Euros. The total export of goods from a free zone, the share of goods produced in the free zone is $99.75 \%$, or EUR 1,415,459,861.00. Compared to 2012, total exports of goods increased by $378.16 \%$, but exports of goods produced in the free zone increased by $377.19 \%$. The mports of goods compared to 2012, also increased by $433.87 \%$. Imports of raw materials increased by $70.39 \%$, while imports of finished products increased by $90.11 \%$. (Ministarstvo finansija Republike Srbije, Uprava za slobodne zone, 2014, p. 6)

Company Fiat cars and the city of Kragujevac founded in 5 November 2009 the Free Zone "FAS", which is primarily intended for the automotive industry. It covers an area of 176 ha 45 a $62 \mathrm{~m}^{2}$ and includes the entire area of the factory cars and Grošnica territory of 29 ha 76 a $19 \mathrm{~m}^{2}$. In the area of "FAS" free zones operate following companies: Fiat Automobiles Serbia and its subcontractors: Magneti Marelli, Johnson Controls Ltd. - the instrument panel, centre console, door panels and rear trim; Magneti Marelli Ltd - front and rear bumper; Magneti Marelli Automotive - exhaust systems HTL - mounting the tire; Johnson Controls - manufacturing seats; Sigit - production of plastic parts and promo Automotive - pressings for vehicles. Companies operating in the zone have the latest techniques and technology used in the automotive industry. Also, they employ 4820 workers, which enables continuous improvement in order to acquire new knowledge and skills. The largest number of employed workers has Free Zone "Pirot" 4.881; 
the second largest is the Free Zone "Kragujevac", and the third Free Zone "Zrenjanin" which employs 2.929 workers.

The work of this zone has a great impact on the business of other undertakings operating in the territory of the Republic of Serbia. In particular, this influence is felt in the economy of the city of Kragujevac, as well as the wider region. The biggest turnover was realized in "FAS Free Zone" Kragujevac and amounts to 3,254,183,796.00 Euros, or $65.94 \%$ of the total realized turnover of goods and services in free zones. Compared to the 2012 the total turnover in this free zone increased by $170.50 \%$, and the value of goods sold and services rendered to $433.87 \%$. (Ministarstvo finansija Republike Srbije, Uprava za slobodne zone, 2014, p. 4). The free zone in Kragujevac, aside from achieving the best results, in comparison to other free zones, performs continuous investments in the most modern equipment and facilities in order to achieve even better results. During 2012 the investments into production models FIAT 500L and increased investment in working capital. The new FIAT car model scored significant success in 2013, when it sold over 100,000 cars, which is in some way fulfilled the expectations of investors.

Based on the previous analysis it can be concluded that in 2013 there was a slight increase in the total results of operations of free zones in the Republic of Serbia in relation to the 2012. It is evident that the positive tendency occurred due to the significant increase in total turnover of goods and services imports in the "FAS Free Zone" from Kragujevac Free Zone "Zrenjanin" and Free Zone "Pirot".

\section{European Experience in the Formation of Free Zones}

Free zones have become increasingly popular in the EU as a tool for attracting foreign direct investment. In the last fifty years free zones became an important part of the strategy of economic development of many EU countries, but only in the last thirty years saw their dynamic development.

The largest free zone in the EU are free port of Hamburg, Free Zone Shannon in Ireland, the zone in Italy (Trieste, Venice), in Austria (Graz, Linz and around Vienna), Spain (Seville), etc. The regulation of free zones in the EU is two-stage, meaning that in the first instance, each Member State shall issue a decision on the opening of free zones and shall inform the European Commission, which appeal brings a positive or negative decision. The operations of free zones in the EU is controlled by the European Commission, but it is noticeable that some "strong" states of the Union, which traditionally have free zones, are reluctant to accept a common legislation. An example is the Free Port of Hamburg, where the German government brokered to be exempted from the obligation of issuing licenses for business users by the legislation of the EU.

Some EU member states have achieved remarkable results in the development of free zones, so that their experiences were very important and serve as an example of good practice. Hereinafter, the authors analyze the experiences of some European countries in the establishment of free zones, namely: Spain, Portugal, Slovakia, Hungary and Italy.

1) Very successful free zone is the EU's Barcelona Free Zone (Zona Franca Barcelona), which includes $16,000 \mathrm{~m} 2$ and within it there are free industrial zones and logistics parks. Within it operates over 100 companies, of which 25 are duty free operators and has, according to some data, about 1000 employ- 
ees. Achieving good results and makes permanent investments in modern technology and transport. Good location and high quality offer stands this zone from other zones that are located on the territory of the EU.

2) Madeira Free Zone is located in Portugal, founded in the early 1980 s by the European Commission, and covers an area of 138 ha. This zone is a little specific and for one reason, and that is it can import goods originating from the EU, but also goods that encourages and from other countries outside the EU, without payment of customs duties and other duties. This zone is constantly achieves good results, while the number of companies within zone time increased from 188 in 1990 to 900 in 2009 . Although the area offers a wide range of customs and tax benefits as well as opportunities to countries that are not members of the EU easier to fit in and engage the EU market, more than 100 companies in 2012 after the budget left the zone. Perhaps one of the reasons for leaving the zone, was just inability to use EU structural funds, as well as increasing the total debt zone.

3) Slovakia has established a free zone in Kosice on an area of 12 hectares. Its existence was not an important factor for the Slovak economy and did not play an important role in attracting foreign investment. (Ministarstvo trgovine SAD, 2002). It was founded in 1994 and by special Law on Free Zones (which was amended in 2008 in accordance with EU rules). Within the zone by 2008 there were more than 200 companies mainly from the field of automotive industry and high tech technologies that have around 9000 employees. In addition to these, companies in Slovakia there are five business innovation centres, which offer plenty of information and provide a great help to small and medium-sized enterprises, to be able to engage in the implementation of modern technologies. The largest inflow of foreign direct investments was made in the automotive industry. Volkswagen near Bratislava made a big factory, where there are also their installations and facilities of their suppliers. In fact, the complex and makes a huge free zone. The car factory Volkswagen Slovakia in 2013 produced a record of 426,313 cars, of which it exported $99.8 \%$ and generated revenue of 6.5 billion Euros in revenue. Otherwise, the factory employs about 9400 people. In addition to Volkswagen, Peugeot, Citroen and Kia have made their factories within the free zone.

4) Hungary has free trade zones which were established under the control of customs services (National Headquarters of the Customs and Finance Guard). In fact, in this country, where the free zones are very popular, there are two types of free zones. The commercial, which are purely commercial in character, and industrial free zones engaged in the production of goods for export.

In Hungary there are 101 free zones. What makes the free zones in Hungary different from free zones in the EU is the fact that a Hungarian company created a free zone, while in other EU countries and more companies operating within the zone. Companies in Hungary operating in the zone have, as in other EU countries, certain benefits and allowances. There are benefits in the form of exemption from payment of tax on goods exported. They realized exports of machinery (electrical, office equipment) in the international market to $90 \%$. It is these companies that contribute to the free zones in Hungary 
achieved outstanding results, while based on some data, these results exceed expectations. In this regard, they are the engine of the Hungarian industry and foreign trade. However, after gaining full EU membership, Hungary had to change its policy on free zones. It is certainly influenced the decrease in free zones, because many companies operating within the zone did not correspond to the new business conditions.

5) Free zones in Italy occurred in the 1970s and 1980s of the twentieth century. Emilia Romagna and Veneto are the two most important regions that have developed legislation on free zones. Veneto has approximately 4.5 million inhabitants and around 1500 free zones and occupies about 25,000 hectares of land. Characteristically for the zones that are located in this region, is that they are usually very small and do not take up space larger than 1,000 ha. Within these zones the most common are operating industrial companies, as the cost of operations in the zone is much smaller than firms operating independently. However, as Italy has benefited from free zones, so their establishment have their bad sides. They are reflected primarily in environmental pollution, then, have a bad influence on agriculture, and cause high costs of building modern infrastructure at multiple locations.

\section{Conclusion}

The free zones in Serbia have much greater benefits than the neighbouring countries, which is the result of favourable geographical position and possession of cheap labour. However, for some long-term success it is necessary to accurately define the objectives, types and directions of development zones. At the same time, it should create a favourable investment environment, through a variety of tax incentives and benefits to companies in the zone, which can have a positive influence on attracting foreign investment.

Group of Free Zones of the Association of Commerce Serbian Chamber of Commerce (PKS) will propose during the 2015 to all relevant ministries and some important institutions of a series of new measures to improve the business in free zones, so that they in some way have become more attractive for foreign investors. Such measures would be related to full exemption from payment of corporate income tax, so it was $0 \%$. Also, measures should be referred to the simplification of the procedure of financing the construction of certain buildings within the zone, as well as customs procedures when importing and exporting goods. A big role in the future development of free zones have local governments that define a series of incentives (tax exemption on earnings of workers, of all newly created jobs, as well as taxes and fees for the construction of new facilities necessary for carrying out production activities within the zone) for successful business zone.

It should be noted that some EU member states have achieved remarkable results in the development of free zones, so that their experiences have very important and serve as an example of good business. In the last fifty years free zones have become an important part of the strategy of economic development of many EU countries, but only in the last thirty years have seen their dynamic development. In addition, it is still very important for EU member States, that goods entering the Zone, which is stored and then transported and finally exported from the Zone, is exempt from all customs formalities. 


\section{References}

Gligorijević, Ž., (2014) Ekonomika industrije. Niš.

Gligorijević, Ž., Petrović, J., (2008) Turizam u funkciji strukturnog prilagodjavanja privrede Srbije, Ekonomika 54 (1-2), 20-26.

http://www.poslodavci-mladenovca.rs/files/slobodne_zone_u_svetu_i_srbiji.pdf (15.2.2015)

Kastrapeli, M. (1971) Modaliteti, funkcionisanja i uloga slobodnih carinskih zona u savremenoj privredi, Beograd.

Kostić, D. (2008) Slobodne proizvodne zone i industrijski parkovi. Zaječar.

Kozomara, J. (2003) Slobodne zone oaze izvoznih podsticaja. Economic Annals 157, 167-178.

Ministarstvo finansija Republike Srbije, Uprava za slobodne zone (2015a) http:// www.usz.gov.rs/aktuelno.php\#44 (6.2.2015.).

Ministarstvo finansija Republike Srbije, Uprava za slobodne zone (2015b) http:// www.usz.gov.rs/aktuelno.php\#45 (6.2.2015).

Ministarstvo finansija Republike Srbije, Uprava za slobodne zone (2015c) http:// www.usz.gov.rs/aktuelno.php\#61 (6.2.2015).

Ministarstvo finansija Republike Srbije, Uprava za slobodne zone (2014) Izveštaj o poslovanju slobodnih zona u 2013. godini. Beograd.

Ministarstvo finansija Republike Srbije, Uprava za slobodne zone, http://www.usz. gov.rs/ (6.2.2015.).

Ministarstvo finansija, Uprava za slobodne zone (2011) Strategija razvoja slobodnih zona u RS od 2011-2016. godine. Beograd.

Ministarstvo trgovine SAD, CEEBIC net.2002. "Privredni vodič Republike Slovačke"

Nešić, B. (1990) Slobodne i carinske zone u bivšoj Jugoslaviji i svetu sa zakonskim propisima i komentarom. Beograd.

Privredna komora Srbije, Centar za privredni sistem (2014) Slobodne zone. http:// www.pks.rs/SADRZAJ/Files/Odbor\%20za\%20privredni\%20sistem/INFORMATOR\%20\%202014.pdf (10.2.2015).

Sl. glasnik RS, Zakon o slobodnim zonama http://www.upravacarina.rs/cyr/Zakoni/ ZAKON\%20O\%20SLOBODNIM\%20ZONAMA-cyr.pdf (05.2.2015).

Stanković, M. (1995) Slobodne zone u Jugoslaviji i u svetu - njihov značaj i uloga na domaću privredu i pravo. Pravo-teorija i praksa 12 (11-12), 60-79.

Takayoshi, K., Tzannatos, Z. (1998) Export processing zones: a review in need of update, social protection group, human development network. The World Bank. Washington, DC.

World Economic Processing Zones Association, WEPZA, http://www.wepza.org $(15.2 .2015)$ 